\title{
Variability of Three Isolates of Botrytis cinerea Affects the Inhibitory Effects of Calcium on this Fungus
}

\author{
Catherine O. Chardonnet, Carl E. Sams, Robert N. Trigiano, and William S. Conway
}

\begin{abstract}
First and second authors: Department of Plant and Soil Sciences, The University of Tennessee, Knoxville 37901; third author: Department of Ornamental Horticulture \& Landscape Design, The University of Tennessee, Knoxville 37901; fourth author: Horticultural Crops Quality Laboratory, Beltsville Agricultural Research Center, Agricultural Research Service, U.S. Department of Agriculture, Beltsville, MD 20705.
\end{abstract}

Accepted for publication 31 March 2000.

\section{ABSTRACT}

Chardonnet, C. O., Sams, C. E., Trigiano, R. N., and Conway, W. S. 2000. Variability of three isolates of Botrytis cinerea affects the inhibitory effects of calcium on this fungus. Phytopathology 90:769-774.

Botrytis cinerea is an economically important pathogen. Epidemiological studies are difficult because of the genetic variability within this species. The objectives of this work were to study the variability and to compare the inhibitory effects of $\mathrm{Ca}$ on three isolates of $B$. cinerea from decayed apple (B) and grape (C and C77:4). Among these isolates, $\mathrm{B}$ had the least radial growth but had a sporulation rate $40 \%$ higher than that of both C77:4 and C. In situ, isolate C incited the largest decay area in the fruit of two of four apple cultivars examined and had the highest polygalacturonase activity in vitro. Maximum mycelial growth was reached with $\mathrm{CaCl}_{2}$ at $1 \mathrm{~g} \mathrm{liter}^{-1}$ for isolates $\mathrm{B}$ and $\mathrm{C} 77: 4$ and at $4 \mathrm{~g} \mathrm{liter}^{-1}$ for isolate C. Calcium $\left(\mathrm{CaCl}_{2}\right)$ inhibited polygalacturonase activity at $1 \mathrm{~g} \mathrm{liter}^{-1}$ for $\mathrm{C}$ and $\mathrm{C} 77: 4$ and at $16 \mathrm{~g} \mathrm{liter}^{-1}$ for B. Calcium infiltration reduced decay caused by all three isolates by three to five times. Mycelial DNA analysis showed that $42 \%$ of the character loci scored were polymorphic and the greatest similarities were found between B and C77:4. These results support the evidence that the biological and statistical variability in research can be affected by the $B$. cinerea isolate selected. Despite this variation, Ca treatment of apples reduced decay caused by all three Botrytis cinerea isolates.

Additional keyword: gray mold.
The genus Botrytis contains 22 species and a large number of host-specific pathogens, such as $B$. fabae Sardina on Leguminosae and B. aclada Fresenius on Allium spp. (7). B. cinerea Pers.:Fr., however, is an important pathogen that can attack more than 200 species in the field (7), greenhouse $(14,35)$, and storage $(28,29,33)$. Under some circumstances, Botrytis-infected grapes can be beneficial for wine production (7). This fungus can infect the plant at every stage of its development and has been found in every part of the plant. Its detection at early stages is difficult because Botrytis spp. can be found in a latent state on the host plant (31), making epidemiological studies difficult.

In vivo, only asexual multinucleate conidia are produced, and field isolates of $B$. cinerea grown on synthetic media exhibit considerable variation (7). Variations can be phenotypic or can result in resistance to fungicides or a change in pathogenicity. These latter variations can make control with fungicides difficult. Mutations and heterokaryosis are the main causes of variations. Nevertheless, the development of resistant strains has provided genetic markers and recognition that distinct genotypic populations of $B$. cinerea exist. No relationship has been found, however, between the existence of different populations and their origins or sources. Because of the emergence of resistance to fungicides, new strategies in the control of $B$. cinerea have been investigated. One alternative involves the use of biocontrol agents including bacteria (21), yeasts (13), or antagonistic fungi $(14,40)$. Calcium improves the efficiency of biological control (45). Several studies have reported that $\mathrm{Ca}$ treatment of plant tissue

Corresponding author: C. E. Sams; E-mail address: carlsams@utk.edu

Publication no. P-2000-0510-01R

This article is in the public domain and not copyrightable. It may be freely reprinted with customary crediting of the source. The American Phytopathological Society, 2000. induces an increase in tissue Ca content (11) by cross-linking the polygalacturonate polymers $(9,10)$, resulting in reduced decay caused by $B$. cinerea $(5,10)$. In addition to the effect of $\mathrm{Ca}$ in strengthening plant cell walls, fungal polygalacturonase (PG) (EC 3.2.1.15), thought to be a key enzyme in the infection process, is inhibited by $\mathrm{Ca}$ (3). All the studies on the effect of $\mathrm{Ca}$ on Botrytis showed that it has an inhibitory effect on growth of this fungus at high concentrations $(3,20,45)$.

The objectives of our work were to characterize the variability among three isolates of $B$. cinerea and their relative responses to $\mathrm{Ca}$ both in vitro and in situ.

\section{MATERIALS AND METHODS}

Fungal isolates. The three isolates of $B$. cinerea used were isolated from decayed 'Golden Delicious' apples (isolate B), [ATCC 90870], from American Type Culture Collection, Manassas, VA) and grapes (isolate C from Cornell University, Ithaca, NY, and isolate C77:4 from the College of Enology, Bordeaux, France). The isolates were grown on potato carrot agar (PCA) slants prepared as follows: $20 \mathrm{~g}$ of diced potatoes and $20 \mathrm{~g}$ of diced carrots were boiled in $\mathrm{H}_{2} \mathrm{O}$ for $30 \mathrm{~min}$ and filtered through cheesecloth. The final volume was adjusted to 1 liter with $\mathrm{H}_{2} \mathrm{O}$, and $15 \mathrm{~g}$ of agar was added. The resulting conidia were transferred from the PCA slants to potato dextrose agar (PDA) (Sigma Chemical Co., St. Louis) plates to produce the necessary inoculum. All incubations were performed at $20^{\circ} \mathrm{C}$ under constant fluorescent light. Ultrapure $\mathrm{H}_{2} \mathrm{O}$ (quality $>18 \mathrm{M} \Omega$ ) was used in all experiments.

Growth on PDA. Plugs ( $0.6 \mathrm{~cm}$ diameter) of fully developed hyphae were placed in the center of a PDA plate, and the mycelial area was recorded over 4 days. Three replicates of each isolate were analyzed. After 5 days, four mycelial plugs $(2 \mathrm{~cm}$ diameter $)$ 
were removed from each plate and mixed with $10 \mathrm{ml}$ of $\mathrm{H}_{2} \mathrm{O}$ for 1 min. The conidial suspension was filtered through two layers of cheesecloth, and the conidial concentration was determined with a hemacytometer. Three replicates of each isolate were analyzed.

Growth in modified Richard's solution. Conidial suspensions $\left(1 \times 10^{6}\right.$ conidia per $\left.\mathrm{ml}\right)$ were prepared from the PDA plates after 2 weeks of growth. Flasks (500-ml) containing $100 \mathrm{ml}$ of Richard's solution, using sucrose at $50 \mathrm{~g} \mathrm{liter}^{-1}(15)$ as the carbon source, were inoculated with $2 \mathrm{ml}$ of the conidial suspension. Four $\mathrm{Ca}\left(\mathrm{CaCl}_{2}\right)$ concentrations at $0,1,4$, and $16 \mathrm{~g} \mathrm{liter}^{-1}$ were added to the media. The $\mathrm{pH}$ of all media was adjusted to 4.2 ( $\mathrm{pH}$ of the medium prior to the addition of $\mathrm{Ca}$ ). The cultures were incubated at $22^{\circ} \mathrm{C}$ on a rotary shaker $(50 \mathrm{rpm})$ under constant light. Mycelia were collected by centrifugation $\left(8,000 \times g, 20 \mathrm{~min}, 4^{\circ} \mathrm{C}\right)$ after 3 , 5,7 , and 10 days and washed three times with $\mathrm{H}_{2} \mathrm{O}$. Hyphae were dried at $70^{\circ} \mathrm{C}$ until dry weight was constant. Four replicates per treatment were analyzed.

Protein and PG activity determination. The three isolates were grown in Richard's solution with $\mathrm{CaCl}_{2}$ added at 0,1 , or 16 $\mathrm{g} \mathrm{liter}^{-1}$. After 5 days, 3-ml aliquots of each culture medium were collected and dialyzed against $\mathrm{H}_{2} \mathrm{O}$ for $16 \mathrm{~h}$ at $4^{\circ} \mathrm{C}$. The protein content (24) and PG activity (17) were determined. Five replicates for each treatment were analyzed.
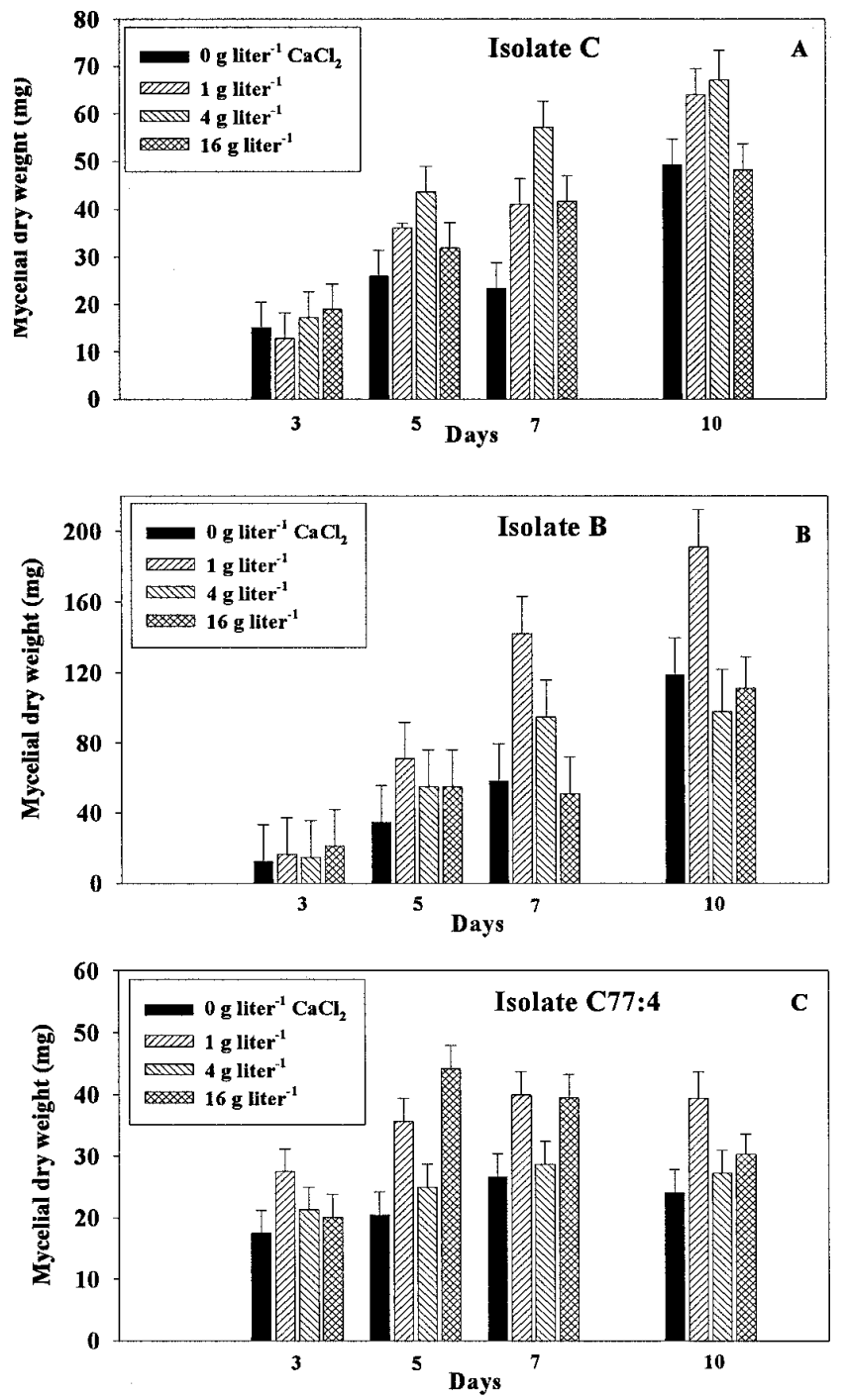

Fig. 1. Effect of calcium on the growth of three isolates of Botrytis cinerea in modified Richard's solution. Data bars are means ( \pm standard error) of four replicates.
Pathogenicity test. Four apple cultivars (Arkansas Black, Golden Delicious, Mutzu, and Rome) stored at $0^{\circ} \mathrm{C}$ for 6 months were used. Fruit from each cultivar were randomized and wounded with the tip of a disinfected 10-penny nail $(2.5 \mathrm{~mm}$ diameter, $3 \mathrm{~mm}$ deep) on two opposite sides of each fruit. Fruit were dipped for $30 \mathrm{~s}$ in a conidial suspension $\left(5 \times 10^{5}\right.$ conidia per $\mathrm{ml}$ ) and incubated at $22^{\circ} \mathrm{C}$. Severity of decay was recorded 5,6 , and 7 days after inoculation by measuring the diameter of the decayed area as the mean of its width and length and computing the total area of decay. Twenty fruit pieces per cultivar were analyzed.

In another experiment, 'Red Delicious' apples were randomized, pressure-infiltrated $(68.95 \mathrm{KPa})$ for 2 min with $6 \%$ $\mathrm{CaCl}_{2}\left(99 \%\right.$ pure), and stored at $0^{\circ} \mathrm{C}$ for 6 months. Fruit were wounded $(2.5 \mathrm{~mm}$ diameter, $3 \mathrm{~mm}$ deep $)$ and inoculated $\left(1 \times 10^{5}\right.$ conidia per $\mathrm{ml}$ ) as described above. The decayed area was measured 5, 6, and 7 days after inoculation. Eighty fruits per isolate were tested.

Statistical analysis. Effects of $\mathrm{Ca}$ treatment, isolate, and time on all variables studied were evaluated by analysis of variance and Duncan's multiple range test was used to compare means. To compare variability among the three isolates, restricted maximum likelihood estimates of residual variances were calculated with the MIXED procedure (SAS Institute, Cary, NC). The model removed all effects of $\mathrm{Ca}$ treatment, isolate, and time when applicable, leaving a pooled residual variance among the replicates. Within this one model, the pooled residual was estimated separately for each isolate (i.e., variability), and those estimates were compared with pairwise $F$ tests (37) between isolates (i.e., significance). The more variable isolate was arbitrarily designated as $* * *$ and the least variable was designated as $*$. Significant $(P<0.01)$ differences between variances were calculated and indicated by a, $\mathrm{b}$, and c. Each experiment was repeated at least twice.

Nuclear staining. Conidia were collected from 2-week-old cultures on PDA and stained with mythramycin (36). Preparations were examined with a fluorescence microscope equipped with a $\mathrm{BV}-2 \mathrm{~A}$ filter, and the number of nuclei per conidium was determined. One hundred observations were made for each isolate.

DNA extraction and analysis. DNA amplification fingerprinting (DAF) was used to assess the genetic relationships between the three $B$. cinerea isolates (4). Mycelia were harvested from 3-day-old potato dextrose broth (Sigma) cultures by filtering through Whatman No. 1 filter paper (Whatman International, Maidstone, England) with a gentle vacuum. The samples were stored at $-75^{\circ} \mathrm{C}$ until needed. Samples consisting of $20 \mathrm{mg}$ of mycelia were ground in liquid $\mathrm{N}_{2}$, and the DNA was extracted according to Yoon et al. (46) as modified by Trigiano et al. (39). Genomic DNA was resuspended in sterile $\mathrm{H}_{2} \mathrm{O}$ and adjusted to 5 $\mathrm{ng} \mathrm{ml}{ }^{-1}$. DNA templates were amplified according to Trigiano et al. (38). Primers (Integrated DNA Technologies Inc., Coralville, IA) used had the following 5' to $3^{\prime}$ sequences: 8.6C: AACGGGTG; 8.6D: GACGTAGG; 8.6F: GATCGCAG; 8.6G: CTAACGCC; 8.6H: GAAACGCC; and 8.7D: CCGAGCTG. DNA was amplified in a thermocycler (Ericomp TwinBlock, San Diego, $\mathrm{CA}$ ) for 35 cycles (each $\approx 5.5 \mathrm{~min}$ ) of denaturing for $10 \mathrm{~s}$ at $96^{\circ} \mathrm{C}$ and followed by annealing for $10 \mathrm{~s}$ at $30^{\circ} \mathrm{C}(38)$. All experiments were repeated twice. Amplified DNA products were used either

TABLE 1. Comparison of the mycelial growth areas (square centimeters) of three isolates of Botrytis cinerea on potato dextrose agar (PDA)

\begin{tabular}{lrrr}
\hline Day & Isolate C & Isolate B & Isolate C77:4 \\
\hline 1 & $1.03 \mathrm{a}^{\mathrm{y}}$ & $0.46 \mathrm{~b}$ & $1.08 \mathrm{a}$ \\
2 & $13.21 \mathrm{a}$ & $5.58 \mathrm{c}$ & $10.20 \mathrm{~b}$ \\
3 & $39.95 \mathrm{a}$ & $30.60 \mathrm{a}$ & $29.51 \mathrm{a}$ \\
Spores $^{\mathrm{z}}\left(\times 10^{-4} / \mathrm{ml}\right)$ & $2.43 \mathrm{~b}$ & $4.00 \mathrm{a}$ & $2.63 \mathrm{~b}$ \\
\hline
\end{tabular}

y Means within a row followed by the same letter are not significantly $(P<$

$0.05)$ different based on Duncan's multiple range test.

${ }^{z}$ Spore concentration was determined after 5 days on PDA. 
directly from the reaction mixture or diluted 1:1 with sterile distilled $\mathrm{H}_{2} \mathrm{O}$. Samples were prepared for electrophoresis by mixing $3 \mu \mathrm{l}$ of product with an equal volume of loading buffer (4) and separated on $0.45-\mathrm{mm}$-thick, $10 \%$ polyacrylamide $7 \mathrm{M}$ urea gels backed on Gelbond polyacrylamide gel electrophoresis with a constant $180 \mathrm{~V}$. DNA was visualized with a fast, sensitive silverstaining procedure that detects picogram quantities of DNA (2). Gels were examined with a light box, and bands of $700 \mathrm{bp}$ or fewer were recorded as either present (1) or absent (0); missing or uncertain data was designated as 9 . All binary data were entered as unordered, nondirected, and unweighted characters by primer and isolate, and Jaccard similarity coefficients were calculated using the Numerical Taxonomy and Multivariate Analysis System, version 1.8 (Exeter Software, Setauket, NY).

\section{RESULTS}

Growth in vitro. The growth of the three isolates of $B$. cinerea on PDA is shown in Table 1 . At 1 and 2 days after inoculation, isolate B had the smallest mycelial growth area. At day 3, no significant $(P<0.05)$ difference in growth area was found between the isolates. After 4 days, the mycelia had covered the 8.3 -cm-diameter agar plate in all samples, with a total growth area of $50 \mathrm{~cm}^{2}$. The conidial concentration was determined after 5 days of growth on PDA. Isolate B produced more conidia than the other isolates, and the sporulation rate of isolate B was $40 \%$ higher than that of isolates $C$ and $C 77: 4$. No visible morphological differences were detected among the three isolates when grown on PDA and microscopically examined. Nuclear staining of the conidia revealed an average of two nuclei per conidium for each isolate.

When grown in liquid culture with modified Richard's solution, isolate $\mathrm{C}$ grew well in the control media (no $\mathrm{Ca}$ added), and mycelial dry weight continued to increase up to 10 days after inoculation (Fig. 1A). Mycelial growth of isolate B followed the same pattern, and the growth rate was twofold higher compared with isolate $\mathrm{C}$ (Fig. 1B). Isolate $\mathrm{C} 77: 4$ had the lowest growth rate in this medium and growth stopped 7 days after inoculation (Fig. 1C). Dry weight of isolate $\mathrm{C}$ increased and growth was stimulated by $\mathrm{Ca}\left(\mathrm{CaCl}_{2}\right)$ concentrations up to $4 \mathrm{~g} \mathrm{liter}^{-1}$. No further stimulation was observed when grown at a concentration of $16 \mathrm{~g}$ liter $^{-1}$ (Fig. 1A). Growth of isolate B was particularly stimulated at the lowest $\mathrm{CaCl}_{2}$ concentration $\left(1 \mathrm{~g} \mathrm{liter}^{-1}\right)$ (Fig. 1B). Maximum growth rate was reached when isolate $\mathrm{C} 77: 4$ was grown at a concentration of $\mathrm{CaCl}_{2}$ of $1 \mathrm{~g} \mathrm{liter}^{-1}$ (Fig. 1C).

Protein secretion and PG activity. Seven days after growth on modified Richard's solution containing $\mathrm{CaCl}_{2}$ at 0,1 , or $16 \mathrm{~g} \mathrm{liter}^{-1}$, the total amounts of exocellular protein and $\mathrm{PG}$ specific activity were determined (Table 2). Total protein secreted by isolates $\mathrm{C}$ and $\mathrm{C} 77: 4$ was not significantly $(P<0.05)$ affected by $\mathrm{CaCl}_{2}$,

TABLE 2. Calcium effect on exocellular protein production and polygalacturonase (PG) activity of three Botrytis cinerea isolates after 7 days of growth in Richard's solution

\begin{tabular}{lccc}
\hline Isolate & $\begin{array}{c}\mathrm{CaCl}_{2} \\
\left(\mathrm{~g} \mathrm{liter}^{-1}\right)\end{array}$ & $\begin{array}{c}\text { Protein secreted }(\mu \mathrm{g} / \mathrm{mg} \\
\text { mycelial dry weight })\end{array}$ & $\begin{array}{c}\text { PG specific activity } \\
\text { (units/ } \mu \mathrm{g} \text { of protein })\end{array}$ \\
\hline & 0 & $14.22 \mathrm{a}^{\mathrm{z}}$ & $2.82 \mathrm{a}$ \\
$\mathrm{C}$ & 1 & $13.40 \mathrm{a}$ & $1.89 \mathrm{~b}$ \\
& 16 & $13.79 \mathrm{a}$ & $1.93 \mathrm{~b}$ \\
$\mathrm{~B}$ & 0 & $10.14 \mathrm{~b}$ & $1.78 \mathrm{a}$ \\
& 1 & $7.58 \mathrm{~b}$ & $2.41 \mathrm{a}$ \\
& 16 & $21.21 \mathrm{a}$ & $0.72 \mathrm{~b}$ \\
$\mathrm{C} 77: 4$ & 0 & $20.44 \mathrm{a}$ & $1.94 \mathrm{a}$ \\
& 1 & $13.20 \mathrm{a}$ & $1.37 \mathrm{~b}$ \\
\hline
\end{tabular}

${ }^{\mathrm{z}}$ Means in the same column within each isolate followed by the same letter are not significantly $(P<0.05)$ different based on Duncan's multiple range test. while both isolates exhibited a significant $(P<0.05) 30 \%$ decrease in PG specific activity when grown on media containing $\mathrm{Ca}$. When grown with a high $\mathrm{Ca}$ concentration, protein production and secretion of isolate B doubled. PG-specific activity, however, was significantly $(P<0.05)$ reduced by $60 \%$ compared with the control.

Pathogenicity. The pathogenicity of each isolate, expressed as the area of decay, was tested on four apple cultivars (Fig. 2). Isolate B was more virulent than isolates $\mathrm{C}$ and $\mathrm{C} 77: 4$ on 'Golden Delicious' apples 7 days after inoculation (Fig. 2A). However, isolate $\mathrm{C}$ was more virulent on 'Muztu' and 'Arkansas' (Fig. 2B and $\mathrm{C}$ ). Virulence levels of isolates $\mathrm{B}$ and $\mathrm{C}$ on 'Rome' were similar to each other (Fig. 2D) and greater than that of isolate C77:4.

To study the effect of $\mathrm{Ca}$ on disease development, $\mathrm{Ca}$-infiltrated 'Red Delicious' apples were inoculated with each isolate (Fig. 3).
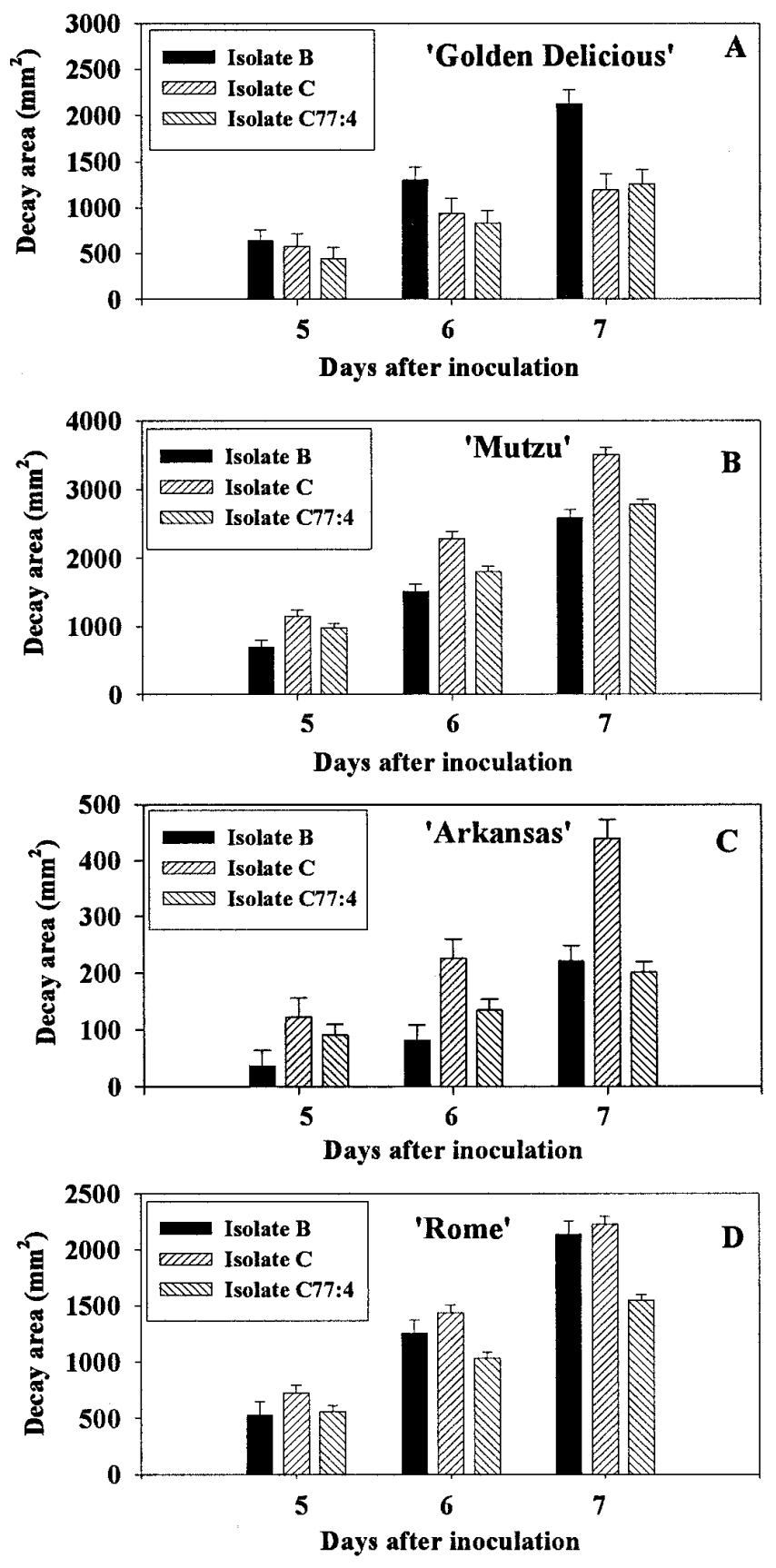

Fig. 2. Pathogenicity of three isolates of Botrytis cinerea on fruits of four apple cultivars. Data bars are means ( \pm standard error) of 20 replicates. 
Calcium infiltration reduced decay caused by each isolate. The effect of $\mathrm{Ca}$ was particularly evident for isolates $\mathrm{C}$ and $\mathrm{C} 77: 4$ (Fig. 3A and B), resulting in a decayed area that was five times less severe than that of control fruit. Decay incited by isolate B was reduced threefold (Fig. 3C).

Statistical analysis. In vitro, the variability in growth among replicates was significantly $(P<0.01)$ different among all three isolates (Table 3). On PDA, isolate B had the most and isolate C had the least variability. In Richard's solution, isolate B still had the most but isolate $\mathrm{C} 77: 4$ had the least variability. Isolate $\mathrm{C} 77: 4$ exhibited the most variability in total protein content. However, isolate C77:4 had the least variability in PG specific activity among replicates. There was no significant $(P<0.01)$ difference in variability among replicates for pathogenicity among the three isolates. Variability in pathogenicity among replicates of the three isolates was not significant across cultivars or Ca treatments.

Genetic variation. DNA analysis of each isolate was performed, and DNA profiles generated by each of the six primers were reproducible. A total of 146 character loci were scored and $61(\approx 42 \%)$ were polymorphic. Figure 4 shows the profiles gene-
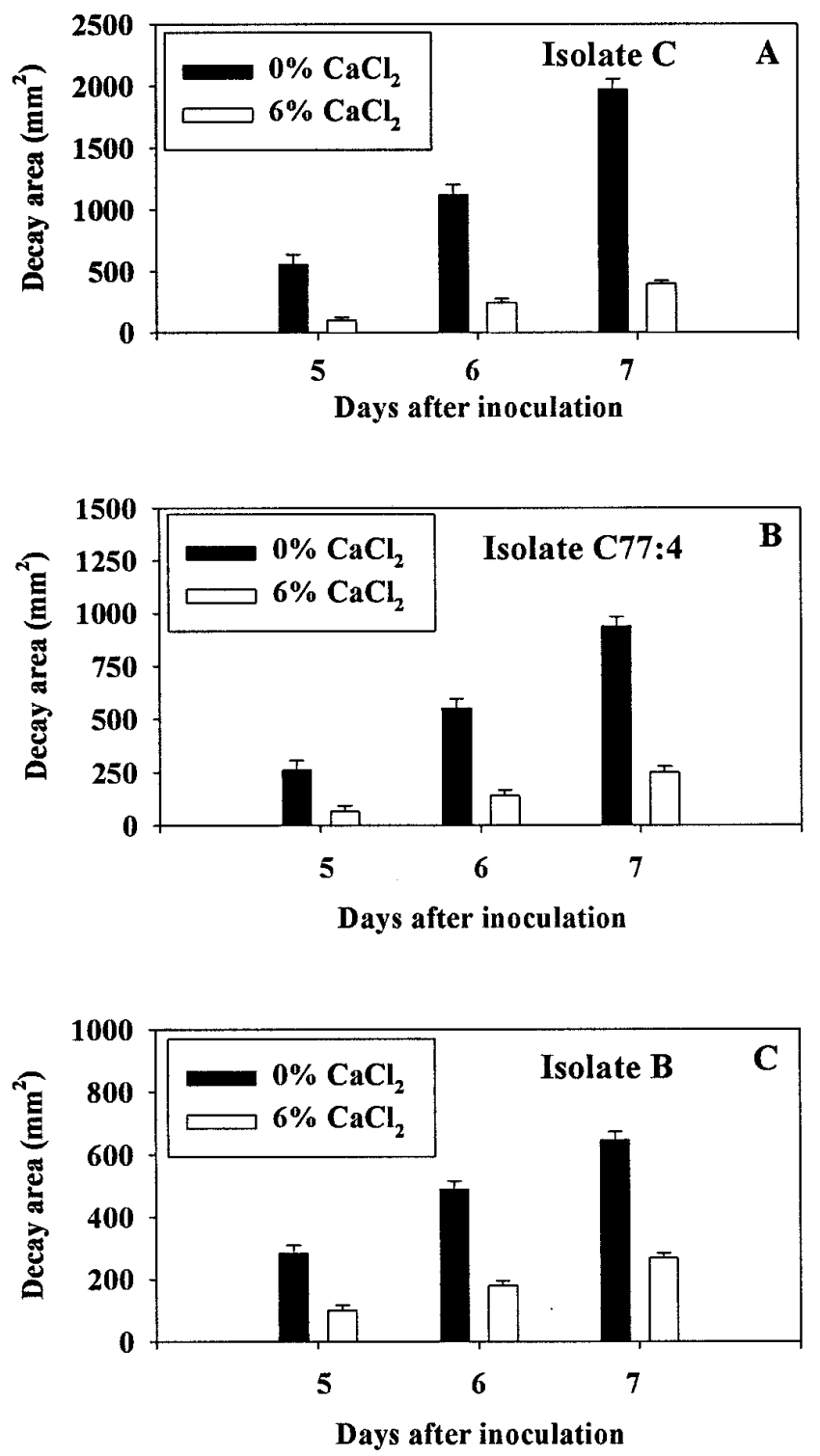

Fig. 3. Effect of calcium infiltration of 'Red Delicious' apples on the pathogenicity of three isolates of Botrytis cinerea. Data bars are means $( \pm$ standard error) of 80 replicates. rated by primers $8.7 \mathrm{D}$ and $8.6 \mathrm{H}$. The calculated Jaccard similarity coefficient indicated that isolates B and C77:4 were more similar to each other than to isolate $\mathrm{C}$ (data not shown).

\section{DISCUSSION}

The three $B$. cinerea isolates used were isolated from different sources (decayed grape and apple), and origins (United States and France), and had each been subcultured numerous times. When grown on PDA, isolate B showed the slowest growth rate during the first 2 days. This slow growth rate might be correlated with the high sporulation rate we observed for this isolate after 5 days on PDA. Variations in growth and sporulation rates have already been shown in different strains and isolates of $B$. cinerea (16), but the determining factor has not yet been elucidated. Isolate B also had the highest growth rate in modified Richard's solution. Variations in fungi are caused mainly by mutation and heterokaryosis (7). Therefore, the more frequently an isolate is subcultured, the higher the possibility of variation. The variation between the three isolates was more apparent in vitro. In situ, all three isolates exhibited the same variability. Each isolate used contained an average of 2 nuclei per conidium, but some Botrytis strains have up to 20 nuclei per conidium (27). This implies that heterokaryosis was limited in the three isolates used in our study. DAF analysis of the three isolates showed that $42 \%$ of the character loci were polymorphic, and the Jaccard similarity coefficient showed that isolates $\mathrm{C} 77: 4$ and $\mathrm{B}$, not related in origin or source, were closer to each other than to isolate C. This agreed with previous work showing that Botrytis strains isolated from the same host were not genetically alike (43).

Fungal mutation is one of the main sources for the emergence of isolates or strains resistant to fungicides (7). Isolate B produced twice as much biomass as isolate $\mathrm{C}$ in Richard's solution. This growth, however, was not related to an increase in protein secreted nor to an increase in PG-specific activity. Nevertheless, some differences observed in vitro were associated with differences observed in situ. No significant difference between isolates was observed regarding the secretion of fungal protein in vitro, but isolate $\mathrm{C}$ showed the highest PG-specific activity and exhibited the highest virulence on two of four apple cultivars. Enzyme activities of Botrytis spp. depend on the isolate or strain (44), particularly pectic enzymes, such as PG, which are involved in the infection process. PG has been studied extensively $(23,42)$ and is composed of isoenzymes whose expression is influenced by the

TABLE 3. Variability estimates from growth, protein content, and pathogenicity data from three isolates of Botrytis cinerea $\mathrm{y}, \mathrm{z}$

\begin{tabular}{|c|c|c|c|}
\hline Variable & Isolate C & Isolate B & Isolate C77:4 \\
\hline \multicolumn{4}{|l|}{ Growth } \\
\hline PDA & $* \mathrm{a}$ & $* * * b$ & $* * \mathrm{c}$ \\
\hline Richard's Solution & $* * \mathrm{a}$ & $* * * \mathrm{~b}$ & $* \mathrm{c}$ \\
\hline \multicolumn{4}{|l|}{ Protein } \\
\hline Total protein & $* * \mathrm{a}$ & $* a$ & $* * * b$ \\
\hline PG specific activity & $* * \mathrm{a}$ & $* * * a$ & $* \mathrm{~b}$ \\
\hline \multicolumn{4}{|l|}{ Pathogenicity } \\
\hline 'Mutzu' & $* * a$ & $* * * a$ & $* \mathrm{a}$ \\
\hline 'Rome' & $* * \mathrm{a}$ & $* * * a$ & $*_{\mathrm{a}}$ \\
\hline 'Arkansas' & $* * * a$ & $* * \mathrm{a}$ & $* \mathrm{a}$ \\
\hline 'Golden Delicious' & $* * \mathrm{a}$ & $* \mathrm{a}$ & $* * * a$ \\
\hline Ca effect on pathogenicity & $* * * a$ & $* \mathrm{a}$ & $* * \mathrm{a}$ \\
\hline
\end{tabular}

y Restricted maximum likelihood estimates of residual variances were calculated using the MIXED procedure. The model removed all effects of $\mathrm{Ca}$ treatment, isolate, and time when applicable, leaving a pooled residual variance among the replicates. Within this model, the pooled residual was estimated separately for each isolate. The more variable isolate was arbitrarily qualified as $* * *$, the least variable as $*$.

z Estimates were compared with pairwise $F$ tests between isolates. Variances within a row followed by the same letter are not significantly $(P<0.01)$ different. 
growth medium (41). The constitutive PG measured in this study has been identified as PG2 and is part of the pool of PG isoenzymes involved in pathogenesis (23). The correlation we found between virulence and PG activity agreed with previous work (42). We also found that isolate B, originally isolated from Golden Delicious, was more virulent on this cultivar, compared with the two other isolates. Since host-specificity has never been found in $B$. cinerea, this result might be purely coincidental. Some apple cultivars were more (Mutzu) or less (Arkansas) susceptible to infection. A number of reasons could explain this observation, such as differences in carbohydrate content (25) or the presence of phenolic compounds $(22,44)$ and phytoalexins $(18,19)$, as well as the quality of the cell wall after 6 months storage at $0^{\circ} \mathrm{C}(1)$.

Calcium is required in minute quantities for mycelial growth (12) and the control medium (Richard's solution) used in our study contained $\mathrm{Ca}$ at $3.74 \mathrm{mg} \mathrm{liter}^{-1}$ (determined by inductively coupled argon plasma atomic emission spectrometry). The cation is involved in several functions, such as synthesis of fungal cell wall polymers, vesicle migration, and tip growth (34). We found that $\mathrm{Ca}$ stimulated growth of all three isolates at low concentration $\left(\mathrm{CaCl}_{2}\right.$ at up to $\left.4 \mathrm{~g} \mathrm{liter}^{-1}\right)$ and that increasing $\mathrm{Ca}$ concentration fourfold in the media did not increase mycelial growth to the same extent. Kaile et al. (20) reported that mycelia cultured with 100 to $200 \mathrm{mM} \mathrm{Ca}^{2+}$ exhibited a lower viability compared with mycelia grown with $10 \mathrm{mM} \mathrm{Ca}$ and $\mathrm{Ca}$ decreased growth rate (45) and PG activity (3) for some isolates of Botrytis spp. Our data showed that low $\mathrm{Ca}$ concentration has no effect on protein secretion but did inhibit PG activity. Polygalacturonase activity of isolates $\mathrm{C}$ and C77:4 was inhibited at low $\mathrm{Ca}$ concentrations, whereas $\mathrm{PG}$ activity of isolate $\mathrm{B}$ was inhibited at higher $\mathrm{Ca}$ concentrations. This difference in susceptibility to Ca inhibition, as well as the difference in PG activity in the control medium, implied that the

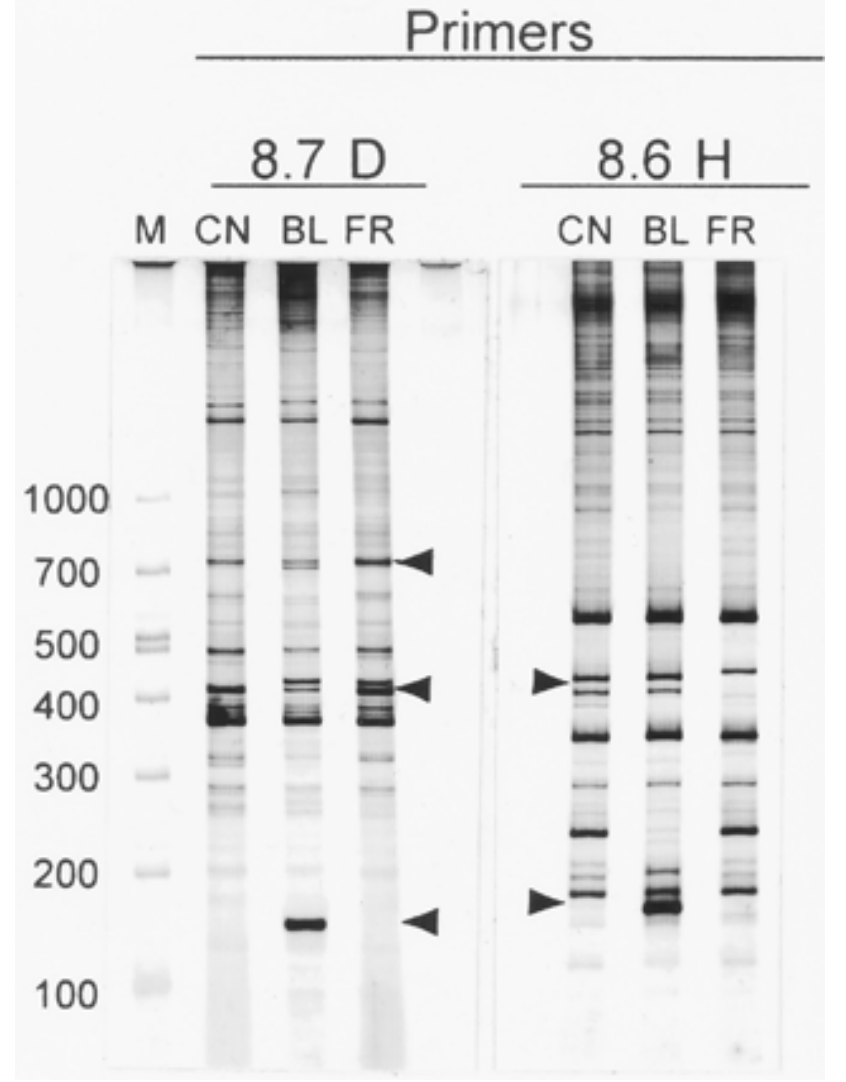

Fig. 4. DNA amplification fingerprinting of three isolates of Botrytis cinerea with primers 8.7D (CCGAGCTG) and 8.6H (GAAACGCC). Some polymorphisms are indicated by arrow heads. $\mathrm{M}=$ molecular weight (base pairs); $\mathrm{CN}=$ isolate $\mathrm{C}$; $\mathrm{BL}=$ isolate $\mathrm{B}$; and $\mathrm{FR}=$ isolate $\mathrm{C} 77: 4$. three isolates produced PGs that were different in their isoenzyme composition, as has been reported for some $B$. cinerea isolates (26).

Calcium infiltration is effective in controlling decay. Externally applied Ca can accumulate in plant tissue (10), especially in the cell wall $(6,9)$, where it cross-links the polygalacturonate polymers. Consequently, the plant cell wall is strengthened, resulting in a reduction in decay caused by $B$. cinerea (8). Previous work showed that when apple fruit were infiltrated with $4 \% \mathrm{CaCl}_{2}, \mathrm{Ca}$ content of the cell wall was increased 5 to 6 times $(1,8)$. Therefore, we could expect the same increase in Ca content of the apple cell wall in our experiment. During the infection process, $\mathrm{Ca}^{2+}$ concentration in the apparent free space (AFS) increased (20) due to the hydrolysis of pectic substances by fungal enzymes. Apparently, the increase in Ca content of the cell wall after infiltration and the consecutive increase in free $\mathrm{Ca}$ in the AFS were sufficient enough to reduce fungal infection by all three isolates.

Resistance to organic and inorganic fungicides has been shown in Botrytis spp., such as resistance to copper sulfate in B. cinerea (30). Calcium is not fungicidal and no resistance to high $\mathrm{Ca}$ concentration has been shown. Biological control of $B$. cinerea has been introduced as an alternative strategy to limit fungal infection. The use of yeasts $(28,32,45)$, bacteria (21), or antagonistic fungi $(14,40)$ has successfully controlled infection by Botrytis spp. in greenhouses and the field. Calcium increases the efficacy of this biological control, presumably by directly affecting spore germination and metabolism of the pathogen and indirectly by not altering the normal metabolism of the biocontrol organism when $\mathrm{Ca}$ is present at high concentrations (45).

Our results indicate that biological and statistical variability can be affected by the $B$. cinerea isolate selected. Despite this variation, $\mathrm{Ca}$ reduces the potential of the fungus to infect the host by limiting fungal growth, inhibiting PG activity, and decreasing plant tissue susceptibility to decay caused by $B$. cinerea.

\section{ACKNOWLEDGMENTS}

We thank B. Donèche (University of Bordeaux II, Bordeaux, France) for providing isolate C77:4; A. Saxton (Department of Statistics, University of Tennessee, Knoxville) for statistical assistance; Pfizer Inc. (Groton, CT) for supplying mythramycin, and Nikon (Melville, NY) for providing filter BV-2A.

\section{LITERATURE CITED}

1. Abbott, J. A., Conway, W. S., and Sams, C. E. 1989. Postharvest calcium chloride infiltration affects textural attributes of apples. J. Am. Soc. Hortic. Sci. 114:932-936.

2. Bassam, B. J., Caetano-Anollés, G., and Gresshoff, P. M. 1991. Fast and sensitive silver staining of DNA in polyacrylamide gels. Anal. Biochem. 196:80-83.

3. Biggs, A. R., El-Kholi, M. M., El-Neshawy, S., and Nickerson, R. 1997. Effects of calcium salts on growth, polygalacturonase activity, and infection of peach fruit by Monilinia fructicola. Plant Dis. 81:399-403.

4. Caetano-Anollés, G., Bassam, B. J., and Gresshoff, P. M. 1991. DNA amplification fingerprinting using very short arbitrary oligonucleotide primers. Bio/Technology 9:553-557.

5. Chardonnet, C. O., and Donèche, B. 1995. Relation entre la teneur en calcium et la résistance à la digestion enzymatique du tissu pelliculaire au cours de la maturation du raisin. Vitis 34:95-98.

6. Chardonnet, C. O., and Donèche, B. 1995. Influence of calcium pretreatment on pectic substance evolution in cucumber fruit (Cucumis sativus) during Botrytis cinerea infection. Phytoparasitica 23:335-344.

7. Coley-Smith, J. R., Verhoeff, K., and Jarvis, W. R. 1980. The Biology of Botrytis. Academic Press, London.

8. Conway, W. S., Gross, K. C., Boyer, C. D., and Sams, C. E. 1988. Inhibition of Penicillium expansum polygalacturonase activity by increased apple cell wall calcium. Phytopathology 78:1052-1055.

9. Conway, W. S., Gross, K. C., and Sams, C. E. 1987. Relationship of bound calcium and inoculum concentration to the effect of postharvest 
calcium treatment on decay of apples caused by Penicillium expansum. Plant Dis. 71:78-80.

10. Conway, W. S., and Sams, C. E. 1983. Calcium infiltration of Golden Delicious apples and its effect on decay. Phytopathology 73:1068-1071.

11. Conway, W. S., Sams, C. E., Abbott, J. A., and Bruton, B. D. 1991. Postharvest calcium treatment of apple fruit to provide broad-spectrum protection against postharvest pathogens. Plant Dis. 75:620-622.

12. Dhingra, O. D., and Sinclair, J. B. 1985. Basic Plant Pathology Methods. CRC Press, Boca Raton, FL.

13. Droby, S., Wisniewski, M. E., Cohen, L., Weiss, B., Touitou, D., Eilam, Y., and Chalutz, E. 1997. Influence of $\mathrm{CaCl}_{2}$ on Penicillium digitatum, grapefruit peel tissue, and biocontrol activity of Pichia guilliermondii. Phytopathology 87:310-315.

14. Eden, M. A., Hill, R. A., and Stewart, A. 1996. Biological control of Botrytis stem infection of greenhouse tomatoes. Plant Pathol. 45:276-284.

15. Fahmy, T. 1923. The production by Fusarium solani of a toxic excretory substance capable of causing wilting in plants. Phytopathology 13:543550.

16. Grindle, M. 1979. Phenotypic differences between natural and induced variants of Botrytis cinerea. J. Gen. Microbiol. 111:109-120.

17. Gross, K. C. 1982. A rapid and sensitive spectrophotometric method for assaying polygalacturonase using 2-cyanoacetamide. HortScience 17:933-934

18. Hrazdina, G., Borejsza-Wysocki, W., and Lester, C. 1997. Phytoalexine production in an apple cultivar resistant to Venturia inaequalis. Phytopathology 87:868-876.

19. Jeandet, P., Sbaghi, M., Bessis, R., Verhoeff, K., Malathrakis, N. E., and Williamson, B. 1992. The use of phytoalexin induction and of in vitro methods as a tool for screening grapevines for resistance to Botrytis cinerea. Pages 109-112 in: Rec. Adv. in Botrytis Res., Proc. 10th Int. Symp. K. Verhoeff and N. E. Malathrakis, eds. Pudoc Scientific Publishers, Wageningen, Netherlands.

20. Kaile, A., Pitt, D., and Khun, P. J. 1992. Calcium cytotoxicity, protoplast viabililty and the role of calcium in soft-rot of Brassica napus due to Botrytis cinerea Pers. Physiol. Mol. Plant Pathol. 40:49-62.

21. Ketterer, N., Fischer, B., Weltzien, H. C., Verhoeff, K., Malathrakis, N. E., and Williamson, B. 1992. Biological control of Botrytis cinerea on grapevine by compost extract and their microorganisms in pure culture. Pages 179-186 in: Rec. Adv. in Botrytis Res., Proc. 10th Int. Symp. K. Verhoeff and N. E. Malathrakis, eds. Pudoc Scientific Publishers, Wageningen, Netherlands.

22. Kritzman, G., and Chet, I. 1980. The role of phenols in the pathogenicity of Botrytis allii. Phytoparasitica 8:27-37.

23. Leone, G. 1990. In vivo and in vitro phosphate-dependent polygalacturonase production by different isolates of Botrytis cinerea. Mycol. Res. 94:1039-1045.

24. Lowry, D. H., Rosebrough, W. J., Farr, A. L., and Randall, R. J. 1951. Protein measurement with the folin phenol reagent. J. Biol. Chem. 193:265-275.

25. Macfoy, C. A., and Smith, I. M. 1985. Interrelationship between nutrients, pathogenicity, and phytoalexin metabolism of Botrytis cinerea on clover leaves. Phytopathology 116:193-200.

26. Magro, P., Di Lenna, P., Marciano, P., and Pallavicini, C. 1980. Variability of polygalacturonase and protein isoelectric focusing patterns in Botrytis cinerea isolates. J. Gen. Microbiol. 120:105-109.

27. Menzinger, W. 1965. Karyologische untersuchungen an arten und formen der gattung Botrytis Mich. Arch. für Mikrobiol. 52:178-196.
28. Mercier, J. and Wilson, C. L. 1995. Effect of wound moisture on the biocontrol by Candida oleophila of gray mold rot (Botrytis cinerea) of apple. Postharvest Biol. Technol. 6:9-15.

29. Michailides, T. J., and Morgan, D. P. 1996. Using incidence of Botrytis cinerea in kiwi fruit sepals and receptacles to predict gray mold decay in storage. Plant Dis. 80:248-254.

30. Parry, K. E., and Wood, R. K. S. 1958. The adaptation of fungi to fungicides: Adaptation to copper and mercury salts. Ann. Appl. Biol. 46:446-456.

31. Powelson, R. L. 1960. Initiation of strawberry fruit rot caused by Botrytis cinerea. Phytopathology 50:491-494.

32. Redmond, J. C., Marois, J. J., and MacDonald, J. C. 1987. Biological control of Botrytis cinerea on roses with epiphytic microorganisms. Plant Dis. 71:799-802.

33. Reyes, A. A. 1990. Pathogenicity, growth and sporulation of Mucor mucedo and Botrytis cinerea in cold or CA storage. HortScience 25:549552.

34. Ruiz-Herrera, J. 1992. Fungal cell wall: Structure, synthesis and assembly. CRC Press, Boca Raton, FL.

35. Sirjusingh, C., and Sutton, J. C. 1996. Effects of wetness duration and temperature on infection of geranium by Botrytis cinerea. Plant Dis. 80:160-165.

36. Slater, M. L. 1976. Rapid nuclear staining method for Saccharomyces cerevisiae. J. Bacteriol. 126:1339-1341.

37. Steel, R. G. D., and Torrie, J. H. 1980. Page 111 in Comparing all means with a control: Principles and procedures of statistics. 2nd ed. McGrawHill, Inc.; New York.

38. Trigiano, R. N., Caetano-Anollés, G., and Windham, M. T. 1995. DNA amplification fingerprinting provides evidence that Discula destructiva, the cause of dogwood anthracnose in North America, is an introduced pathogen. Mycologia 87:490-500.

39. Trigiano, R. N., Gerhaty, N. E., Windham, W. T., and Brown, D. A. 1991. A simple assay for separating fungi associated with dogwood anthracnose. Proc. of S. Nursery-men's Assoc. Res. Conf. 36:209-211.

40. Tronsmo, A., and Dennis, C. 1974. The use of Trichoderma species to control strawberry fruit rots. Neth. J. Plant Pathol. 83:449-455.

41. Van Den Heuvel, J., and Waterreus, L. P. 1985. Pectic enzymes associated with the phosphate-stimulated infection of French bean leaves by Botrytis cinerea. Neth. J. Plant Pathol. 91:253-264.

42. Van Der Cruyssen, G., Kamoen, O., Verhoeff, K., Malathrakis, N. E., and Williamson, B. 1992. Polygalacturonases of Botrytis cinerea. Pages 6975 in: Recent Advances in Botrytis Research, Proc. 10th Int. Symp. K. Verhoeff and N.E. Malathrakis, eds. Pudoc Scientific Publishers, Wageningen, Netherlands.

43. Van Der Vlugt-Bergmans, C. J. B., Brandwagt, B. F., Vant Klooster, J. W., Wagemakers, C. A. M., and Van Kanj, J. A. L. 1993. Genetic variation and segregation of DNA polymorphisms in Botrytis cinerea. Mycol. Res. 97:1193-1200.

44. Wasfy, E. M., Farag, S. A., Tarabieh, M. A., and Abd-Elmoety, S. M. 1978. Studies on enzymes of different strains of Botrytis cinerea. Phytopathology 92:168-179.

45. Wisniewski, M., Droby, S., Chalutz, E., and Eilam, Y. 1995. Effects of $\mathrm{Ca}^{2+}$ and $\mathrm{Mg}^{2+}$ on Botrytis cinerea and Penicillium expansum in vitro and on the biocontrol activity of Candida oleophila. Plant Pathol. 44:1016-1024.

46. Yoon, C. K., Glawe, D. A., and Shaw, P. D. 1991. A method for rapid small-scale preparation of fungal DNA. Mycologia 83:835-838. 